\title{
Farm Credit Developments In the Central Mississippi Valley
}

\begin{abstract}
To 10 GAIN a better understanding of how commercial banks are meeting the changing credit demands of agriculture, the Federal Reserve System conducted a farm loan survey in mid-1966. The survey covered 159 banks in the Central Mississippi Valley and 1,607 banks in the United States. ${ }^{1}$ It was designed to obtain specific characteristics of bank loans: original and outstanding amounts, maturity, interest rates, purpose and security. Various borrower characteristics such as age, tenure, income, asset and net-worth positions, type of operation, and location with respect to the bank were also sought.
\end{abstract}

Comparisons are made in the first part of this article with the findings of a similar survey conducted in 1956. The second part of the article discusses the impact of changes in agriculture on credit demands.

1 The selection of banks for inclusion was on a stratified random sampling basis. All data for which no source is given were obtained from the Federal Reserve survey. In discussing the survey data, the term "Central Mississippi Valley" is synonomous with the Eighth District.

\section{Farm Loan Survey}

Based on the survey, 277 thousand farm borrowers had 450 thousand loans outstanding which totaled $\$ 1.2$ billion at all commercial banks in the Central Mississippi Valley in mid-1966. This was 10 per cent fewer agricultural loans than in 1956, but the dollar volume was about 2.5 times greater. Average size of farm debt to banks per borrower in the region rose about threefold during the decade.

Farm borrowers at Central Mississippi Valley banks had smaller average annual sales than such borrowers in the United States as a whole. About 55 per cent of borrowers at commercial banks in the Valley states sold less than $\$ 10,000$ worth of farm products annually while only 12 per cent reported sales in excess of $\$ 20,000$. By comparison, less than 50 per cent of such borrowers in the nation had sales below $\$ 10,000$, and more than 15 per cent had sales in excess of $\$ 20,000$ (Table I).

In the Valley states more than one-third of bank

Table

PERCENTAGE DISTRIBUTION OF BORROWERS BY TYPE OF FARM AND GROSS SALES AT CENTRAL MISSISSIPPI VALLEY BANKS

(Mid-1966)

Type of Form

Meał Animals
Dairy
Poultry
Cash Grain
Cotton
Other Major Products
General
Not Reported

Total Region

Total United States

- less than 0.05 per cent

Gross Sales

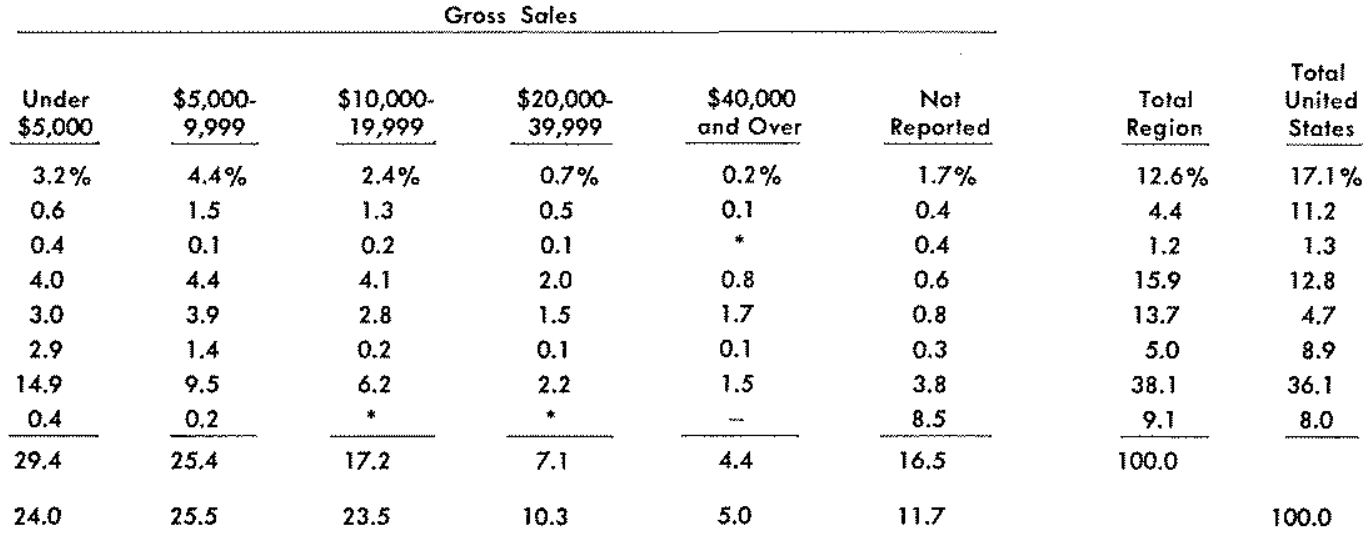

Page 8 
Table II

PERCENTAGE DISTRIBUTION OF OUTSTANDING LOAN AMOUNT BY TYPE OF FARM AND GROSS SALES AT CENTRAL MISSISSIPPI VALLEY BANKS

\begin{tabular}{|c|c|c|c|c|c|c|c|c|}
\hline \multirow{3}{*}{ Type of Farm } & \multicolumn{6}{|c|}{ (Mid-1966) } & \multirow[b]{3}{*}{$\begin{array}{c}\text { Totol } \\
\text { Region }\end{array}$} & \multirow[b]{3}{*}{$\begin{array}{l}\text { Total } \\
\text { United } \\
\text { States }\end{array}$} \\
\hline & \multicolumn{6}{|c|}{ Gross 5oles } & & \\
\hline & $\begin{array}{l}\text { Under } \\
\$ 5,000 \\
\end{array}$ & $\begin{array}{c}\$ 5,000- \\
9,999 \\
\end{array}$ & $\begin{array}{c}\$ 10,000- \\
19,999 \\
\end{array}$ & $\begin{array}{c}\$ 20,000- \\
39,999 \\
\end{array}$ & $\begin{array}{c}\$ 40,000 \\
\text { and Over }\end{array}$ & $\begin{array}{c}\text { Not } \\
\text { Reported }\end{array}$ & & \\
\hline Meat Animals & $1.8 \%$ & $4.0 \%$ & $3.3 \%$ & $1.5 \%$ & $1.9 \%$ & $1.0 \%$ & $13.5 \%$ & $27.7 \%$ \\
\hline Dairy & 0.3 & 1.0 & 2.0 & 1.2 & 0.4 & 0.2 & 5.1 & 11.0 \\
\hline Poultry & 0.1 & 0.2 & 0.4 & 0.3 & $*$ & 0.2 & 1.2 & 1.6 \\
\hline Cash Grain & 1.9 & 4.1 & 4.3 & 4.0 & 3.7 & 0.6 & 18.0 & 12.3 \\
\hline Cotton & 1.0 & 1.8 & 3.0 & 3.6 & 5.2 & 0.9 & 15.5 & 4.5 \\
\hline Other Mojor Products & 0.9 & 0.8 & 0.6 & 0.2 & 0.8 & 0.1 & 3.4 & 9.0 \\
\hline General & 6.2 & 6.9 & 8.3 & 5.6 & 6.3 & 3.5 & 36.8 & 28.9 \\
\hline Not Reporled & 0.4 & 0.2 & $*$ & ${ }^{*}$ & - & 5.9 & 6.5 & 4.9 \\
\hline Total Region & 12.6 & 19.0 & 21.9 & 16.4 & 17.7 & 12.4 & 100.0 & \\
\hline Total Unifed States & 7.9 & 3.1 & 23.4 & 19.4 & 28.1 & 7.0 & & 100.0 \\
\hline
\end{tabular}

borrowers operate general farms, ones on which there is no single product accounting for 50 per cent of gross sales. Almost one-sixth of all such borrowers operated farms having annual sales of less than $\$ 5,000$.

Of the specialized types of farms operated by bank borrowers, cash grain farms are the most numerous, accounting for 16 per cent of the total. Next in order are cotton and meat animal farms, accounting for 14 and 13 per cent of the total, respectively. The distribution of borrowers in the United States by type of farm does not differ greatly from the Valley states, except for cotton farmers, who account for only 5 per cent of the nation's total.

Total volume of debt to banks is fairly evenly distributed among the size groups of Eighth District farms. For example, the largest volume of debt to banks ( 21.9 per cent) was owed by farmers having gross sales of $\$ 10,000$ to $\$ 19,999$, while the smallest volume (12.6 per cent) was owed by farmers with gross sales of less than $\$ 5,000$ (Table II). In certain specialized types of farms, however, most credit was extended to farmers in the larger size groups. More than one-half the bank credit to cotton farmers and almost half that to cash grain farmers was owed by those with cash sales in excess of $\$ 20,000$ per year. Nationally, farmers with sales of less than $\$ 5,000$ owed a smaller proportion of the outstanding credit than did farmers in the Eighth District.

\section{Purpose and Security}

Information on the purpose of loans showed that most farm credit extended by Central Mississippi
Valley banks was used to purchase equipment and farm land, and for current operating and family living expenses. Each of these categories accounted for more than one-fifth of all credit extended to farmers in 1966 (Table III). Other major purposes for farm credit included purchases of feeder livestock, other livestock, and improvement of land and buildings, each accounting for 6 to 7 per cent of the total.

Nationally, the share of credit extended for purchasing feeder livestock and other livestock was well above that of the region. Credit for purchasing farm equipment and real estate, however, represented a smaller proportion of the total in the nation than in the region.

Changes in major purpose of farm loans from 1956 to 1966 reflect broad adjustments in the region during the decade. Credit for current operating and family living expenses declined from 33 per cent of the total in 1956 to 28 per cent in 1966. Bank credit for farm machinery and equipment increased from 14 to 20 per cent of the total as the general uptrend in farm mechanization and automation continued. Bank credit for purchasing farm real estate rose from 20 to 22 per cent of the total as incentive for farm consolidation and enlargement contributed to the rising demand for land. Credit to consolidate or pay debts declined somewhat relative to the total during the decade.

Chattel mortgages are the most common collateral for farm loans in the Central Mississippi Valley, being used for 43 per cent of all credit outstanding. Next in importance are real estate mortgages, accounting for almost 30 per cent of the total. About one-sixth of all farm credit at banks was unsecured, 5 per cent of the 
total was endorsed or had a co-maker, and 4 per cent was Government guaranteed or insured.

Nationally, more than 50 per cent of all farm credit by banks was secured by chattel mortgages, while only 20 per cent was secured by farm real estate mortgages. A slightly larger proportion of bank loans to farmers was unsecured in the nation than in the Central Mississippi Valley.

\section{Terms}

The practice of making short-term loans for financing current expenses is quite prevalent in both the region and nation. Loans with maturities of 7 months or less accounted for 30 per cent of all bank loans to farmers in the Central Mississippi Valley in mid-1966, and those with 8-month to 13-month maturities accounted for an additional 37 per cent (Table IV). Loans with 14-month to 42-month maturities were made chiefly for the purchase of nonfeeder livestock, equipment, consumer durables, and improvements to land and buildings. The long-term Ioans, 43 months and over, were primarily for the purchase of real estate. Nationally, a somewhat larger per cent of loans was concentrated in the short-term groups than in the region. For example, 39 per cent were made to mature in seven months or less, while only 12 per cent had maturities of 43 months and over.

During the decade, maturities of bank credit to farmers lengthened significantly. The proportion of notes maturing on demand or in less than 8 months declined from 45 per cent in 1956 to 30 per cent in 1966. A larger proportion of the loans outstanding in mid-1966 matured in each of the longer periods ( 8 to 13 months, 14 to 42 months, and 43 months and over), than a decade earlier. This lengthening of maturities is more in line with the expected flow of returns from additional farm investments. In this respect farm credit supplies have adjusted to demands as indicated by farm capital requirements and repayment capacity.

Table H1

\section{PERCENTAGE DISTRIBUTION OF FARM CREDIT OUTSTANDING BY PURPOSE AND SECURITY AT CENTRAL MISSISSIPPI VALLEY BANKS \\ $(\mathrm{Mid}-1966)$}

Maior Purpose of Laan

1956
Feeder livestock
Other livestock
Equipment
Current operating and family
Iiving expenses
Auto or ofher consumer durables
Consolidate or poy debts
Farm real estale
Improve land and buildings
Other
Total Region

Maior Security

\begin{tabular}{|c|c|c|c|c|c|c|c|}
\hline Unsecured & $\begin{array}{c}\text { Endorsed or } \\
\text { Co-maker } \\
\end{array}$ & $\begin{array}{c}\text { Chattel } \\
\text { Mortgoge } \\
\end{array}$ & $\begin{array}{c}\text { Farm Real } \\
\text { Estote Mortgage } \\
\end{array}$ & $\begin{array}{l}\text { Government } \\
\text { Guaranteed } \\
\text { of Insured }\end{array}$ & Other & $\begin{array}{c}\text { Total } \\
\text { Region }\end{array}$ & $\begin{array}{l}\text { Tolal } \\
\text { United } \\
\text { States }\end{array}$ \\
\hline $2.8 \%$ & $0.3 \%$ & $2.8 \%$ & $0.6 \%$ & $*$ & $*$ & $6.5 \%$ & \\
\hline 2.0 & 0.5 & 3.7 & 0.4 & - & 0.6 & 7.2 & \\
\hline 1.1 & 1.3 & 10.3 & 0.8 & 0.3 & 0.3 & 14.1 & \\
\hline 10.2 & 2.1 & 18.1 & 2.1 & * & 0.8 & 33.3 & \\
\hline 0.2 & 0.3 & 1.6 & 0.2 & - & $*$ & 2.3 & \\
\hline 0.8 & 0.4 & 1.5 & 4.2 & - & 0.2 & 7.1 & \\
\hline 1.0 & 0.4 & 0.3 & 17.3 & 1.3 & 0.1 & 20.4 & \\
\hline 0.8 & 0.3 & 0.5 & 4.2 & * & 0.1 & 5.9 & \\
\hline 0.7 & 0.5 & 0.5 & 9.2 & - & 0.3 & 3.2 & \\
\hline 19.6 & 6.1 & 39.3 & 31.0 & 1.6 & 2.4 & 100.0 & \\
\hline
\end{tabular}

\begin{tabular}{|c|c|c|c|c|c|c|c|}
\hline $2.2 \%$ & $0.1 \%$ & $3.7 \%$ & $0.2 \%$ & - & $0.2 \%$ & $6.4 \%$ & $15.6 \%$ \\
\hline 1.0 & 0.1 & 4.8 & 0.5 & - & * & 6.4 & 10.6 \\
\hline 2.0 & 0.9 & 36.1 & 0.7 & - & 0.3 & 20.0 & 14.6 \\
\hline 8.4 & 2.0 & 14.0 & 1.6 & - & 1.5 & 27.5 & 28.8 \\
\hline 0.3 & 0.1 & 2.1 & 0.1 & - & $*$ & 2.6 & 2.2 \\
\hline 0.3 & 0.7 & 1.0 & 2.1 & - & 0.2 & 4.3 & 4.6 \\
\hline 0.2 & - & - & 19.0 & 2.7 & - & 21.9 & 15.2 \\
\hline 1.4 & 0.4 & 0.4 & 3.6 & 0.8 & 0.1 & 6.7 & 4.8 \\
\hline 0.8 & 0.3 & 1.2 & 1.3 & $\because$ & 0.6 & 4.2 & 3.6 \\
\hline 16.6 & 4.6 & 43.3 & 29.1 & 3.5 & 2.9 & 100.0 & \\
\hline 21.4 & 3.3 & 50.7 & 20.2 & 1.5 & 2.8 & & 100.0 \\
\hline
\end{tabular}

*less than 0.05 per cent.

Page 10 
Toble IV

PERCENTAGE DISTRIBUTION OF FARM CREDIT OUTSTANDING BY MAJOR PURPOSE AND TERM OF LOAN AT CENTRAL MISSISSIPPI VALLEY BANKS

\begin{tabular}{|c|c|c|c|c|c|c|c|c|c|c|c|c|c|}
\hline \multirow[b]{2}{*}{ Majoz Purpose } & \multicolumn{6}{|c|}{1956} & \multicolumn{6}{|c|}{1966} & \multirow[b]{2}{*}{$\begin{array}{l}\text { Tolal } \\
\text { United } \\
\text { States } \\
\end{array}$} \\
\hline & Demand & $\begin{array}{c}1.7 \\
\text { Months }\end{array}$ & $\begin{array}{c}8.13 \\
\text { Months }\end{array}$ & $\begin{array}{c}14-42 \\
\text { Months }\end{array}$ & $\begin{array}{c}43 \\
\text { Monfhs } \\
\& \text { Oret } \\
\end{array}$ & $\begin{array}{c}\text { Totol } \\
\text { Region }\end{array}$ & Demand & $\begin{array}{c}1-7 \\
\text { Months } \\
\end{array}$ & $\begin{array}{c}8.13 \\
\text { Months }\end{array}$ & $\begin{array}{c}14-42 \\
\text { Months } \\
\end{array}$ & $\begin{array}{l}43 \\
\text { Months } \\
\& \text { Over } \\
\end{array}$ & $\begin{array}{c}\text { Total } \\
\text { Region }\end{array}$ & \\
\hline $\begin{array}{l}\text { Buy nonfeeder livestock, } \\
\text { equipment, consumer } \\
\text { durables, improve lond } \\
\text { and buildings }\end{array}$ & $2.3 \%$ & $8.5 \%$ & $8.6 \%$ & $7.6 \%$ & $2.4 \%$ & $29.4 \%$ & $2.6 \%$ & $6.5 \%$ & $11.6 \%$ & $10.7 \%$ & $4.3 \%$ & $35.7 \%$ & $32.2 \%$ \\
\hline $\begin{array}{c}\text { Purchase feeder livestock, } \\
\text { curtent operating and } \\
\text { family living expenses }\end{array}$ & 4.3 & 21.8 & 12.4 & T. 1 & 0.3 & 39.9 & 3.2 & 11.1 & 16.9 & 1.4 & 1.2 & 33.8 & 44.4 \\
\hline $\begin{array}{l}\text { Consolidale or pay other } \\
\text { debts }\end{array}$ & 1.0 & 2.2 & 2.1 & 0.5 & 1.4 & 7.2 & 0.6 & 1.0 & 1.0 & 0.4 & 1.3 & 4.3 & 4.6 \\
\hline Buy farm real estafe & 0.9 & 2.4 & 5.7 & 2.4 & 9.0 & 20.4 & 1.9 & 1.8 & 5.7 & 1.6 & 11,0 & 22.0 & 15.2 \\
\hline Other purposes & 0.5 & 1.0 & 0.8 & 0.2 & 0.6 & 3.1 & 0.3 & 7.4 & 1.3 & 0.3 & 0.9 & 4.2 & 3.6 \\
\hline All purposes region & 9.0 & 35.9 & 29.6 & 11.8 & 13.7 & 100.0 & 8.6 & 21.8 & 36.5 & 14.4 & 18.7 & 100,0 & \\
\hline All purposes United States & & & & & & & 7.4 & 32,0 & 33.5 & 14.8 & 12.0 & & 100.0 \\
\hline
\end{tabular}

\section{Interest Rates}

Interest charged on bank loans tended to vary with the purpose of loan and the method of repayment. In the region, average effective rates varied by purpose from a low of 6.1 per cent for real estate loans to 8.2 per cent for automobile loans. ${ }^{2}$ As a general rule, instalment loans with interest added on or discounted have higher effective interest rates than other loans. Included in this category are a large proportion of automobile and consumer durable loans, and a somewhat smaller proportion of farm equipment loans. In contrast, loans for purchasing feeder cattle, other livestock, other current expenses, and real estate are generally single-payment loans or instalment loans with interest charged on the outstanding loan balance.

The effective interest rate on both single-payment loans and instalment loans, with interest charged on the outstanding balance, averaged 6.4 per cent. In contrast, the effective rate for add-on instalment loans averaged 10.6 per cent, and for discounted instalment loans 12.1 per cent.

Other factors which apparently infuence the rate of interest charged are origin of loan, amount of original loan, and gross sales and net worth of borrower. Among purchased notes, those which originated with merchants or dealers had the highest rate, averaging 8.5 per cent. Those obtained from the Farmers Home Administration, which are Government guaranteed, averaged 5 per cent, the lowest of any group.

${ }^{2}$ All rates were computed to an effective rate basis, taking into account any compensating bolance requirements, as well as compounding of interest on all instalment loars including those with interest charged on the outstanding balance.
Average interest rates declined steadily with increasing size of notes. The average rate charged on notes of less than $\$ 250$ was 7.2 per cent, while the rate on notes of $\$ 100,000$ and over averaged 6 per cent. Rates charged were generally lower to borrowers with high gross sales, possibly reflecting the larger average size of loans. Animal, dairy, and cash grain farmers with sales of $\$ 40,000$ and over per year were charged a significantly lower average rate than those with sales of $\$ 5,000$ and under. For other types of farms, which are located primarily in Kentucky and Tennessee, rates did not decline as sales per farm rose. All rates in these states probably reached the legal maximum on such loans.

Interest rates charged also declined as the net worth of borrowers increased. Rates varied from an average of 6.9 per cent for those farmers with a net worth of less than $\$ 3,000$ to 6.4 per cent for those with a net worth in excess of $\$ 100,000$. Interest rates were even more varied by net worth of farmers under 35 years of age. The rate varied from 7.1 per cent for those with a net worth of under $\$ 3,000$ to 6.1 per cent for those with a net worth in excess of $\$ 100,000$.

The average interest rate on bank loans to farmers in the nation was 6.7 per cent, the same as in the Central Mississippi Valley (Table V). Interest rates in both Kentucky and Tennessee were lower, while in Arkansas the average was somewhat higher.

\section{Participation Loans}

Participation loans originated by Central Mississippi Valley banks represented about 4 per cent of total bank loans to farmers in mid-1966. A decade earlier 


\section{Table $\vee$ \\ AVERAGE EFFECTIVE INTEREST RATES ON AGRICULTURAL LOANS OUTSTANDING AT CENTRAL MISSISSIPPI VALLEY BANKS (June 30, 1966)}

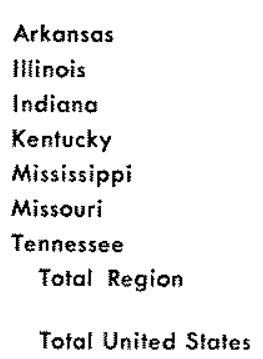

\begin{tabular}{c} 
Per Cent \\
\hline 7.1 \\
6.6 \\
6.6 \\
6.7 \\
6.6 \\
6.7 \\
6.2 \\
\hline 6.7 \\
6.7
\end{tabular}

such loans accounted for only about 2 per cent of the farm debt held by area banks. Principal reasons for the rise in participation loans involve both the size of loan request relative to lending limits of the bank, and the large demand for additional loanable funds relative to supply in a local community.

Statutory limitations, based on size of a bank's capital account, put a ceiling on the amount that can be loaned to one individual or business. Bank capital accounts have grown about 7 per cent per year during the past decade compared with an annual increase of 13 per cent in liabilities per farm. As a result, a greater proportion of farm loan requests have probably exceeded individual bank lending limits, thus increasing the need for correspondent banks to take these overlines.

Basic shortages in local loanable funds relative to national conditions may also develop in the relatively isolated markets typical of many rural communities. These shortages may be temporary, reflecting a seasonal decline in deposits coincident with peak loan demand. On the other hand, they may be of a long-run nature, suggesting higher marginal returns to capital in a local community than in the nation. In either case, the higher interest rates necessary for equating supply and demand for funds locally should attract outside funds into the market, provided financial institutions are available to perform this function. Loan participations are a means by which banks can meet large local demand for funds relative to supply, thereby improving the nation's allocation of capital.

Most participation loans in the Central Mississippi Valley originated at small banks. Approximately threefifths of the total originated at banks having total capital and surplus of less than $\$ 200,000$, while only about 10 per cent originated at banks having total capital and surplus in excess of $\$ 2$ million.

Approximately 50 per cent of the amount of all participation loans originating at respondent banks were made for current operating expenses. About 25 per cent were for purchasing stock animals, 12 per cent for feeder livestock, and 10 per cent for equipment.

\section{Farm Credit Trends Reflect Changes In Agriculture}

The previous portion of the article was limited to reporting borrower and loan characteristics of bank lending to agriculture and was based on Federal Reserve System surveys. The remainder of the article, however, is based primarily on USDA data and describes changes in the structure of agriculture and the impact of these changes on credit demand in both the region and nation.

The terms and quantity of farm credit demand in the Central Mississippi Valley and in the nation reflect major changes in the structure of agriculture. Credit availability may, in turn, have facilitated structural adjustments in response to new technology and market conditions.

During the past decade the financial structure of agriculture in the United States changed at a rapid rate. Total assets rose from $\$ 170$ billion in 1956 to $\$ 256$ billion in 1966 , reflecting both steadily rising land values and rising capital ituputs such as machinery, equipment, and livestock. At the same time the num" ber of individual farms declined. With the trend toward larger and fewer farms, the decade experienced an even sharper increase in assets per farm. Assets per farm more than doubled during the period, increasing from $\$ 37,600$ to $\$ 78,700$, a rate of 7.7 per cent per year (Table VI).

Total farm debt advanced at a faster rate than assets, rising from $\$ 18.7$ billion to $\$ 41.5$ billion during the decade. Debt per farm more than tripled, rising from $\$ 4,150$ to $\$ 12,750$, an annual rate of 12 per cent, and debt relative to assets increased from 11 per cent to 16 per cent. Equity per farm rose at a 7 per cent rate.

The changing financial structure of agriculture is associated with an increase in size and productivity of farms, and a decline in use of farm labor. Average size of farms in the nation rose from 265 to 351 acres,

\footnotetext{
"In this section the term "Central Mississippi Valley" refers to the states of Arkansas Kentucky Mississippi, Missouri, and Tennessee combined. Avallability of data trecessitates use of entire states which results in some deviation from the defnition of the Central Mississippi Valley used earlier in the article.
} 
a rate of gain of 3 per cent per year during the decade. As indicated by cash receipts, output per farm doubled, and an almost equal rate of gain was achieved in net income. Despite major gains in farm size and output, workers per farm declined from 1.7 in 1956 to 1.6 in 1966. The number of farm workers in the nation dropped from 7.8 to 5.3 million during the past ten years, an average annual decline of 3.9 per cent. The share of the nation's civilian labor force in agriculture declined from 12 to 7 per cent.

Generally, trends in the Central Mississippi Valley were similar to those in the nation. Total farm assets rose at a rate of 4 per cent per year, while assets per farm rose at a rate of 8 per cent. Liabilities rose at a 13 per cent rate. Debt as a proportion of assets rose from 10 to 16 per cent.

Changes in size, output, and use of labor per farm in Central Mississippi Valley states were generally consistent with the national trend. The increase in acreage per farm of 2.4 per cent per year in the Valley states was somewhat below the national rate, and the increase in output of 6.7 per cent per year almost equaled that of the nation. On the other hand, the 4.2 per cent per year decline in farm workers exceeded the national rate.

These data, both for the nation and for the region, indicate the capacity of agriculture to make changes as technological and market forces provide incentive for such developments. However, rates of change have varied widely among the Valley states. For example, in those states with lowest average acres per farm, namely Tennessee and Kentucky, the rates of increase in acres per farm were also below average, 1.9 and 1.4 per cent per year, respectively (Table VI). By comparison, the average rate of increase was 3.2 per cent for the three other area states and 2.9 per cent for the nation as a whole. Total number of farm workers declined at annual rates of 2.2 per cent and 2.6 per cent in Kentucky and Tennessee, respectively, compared to an average rate of 5.4 per cent in the three other area states and 3.9 per cent in the nation.

More important than farm size from a welfare viewpoint, however, is farm output. Measured either in terms of cash receipts or net income per farm, Ten-

Jable V!

IMPORTANT AGRICULTURAL CHANGES IN CENTRAL MISSISSIPPI VALLEY STATES

\begin{tabular}{|c|c|c|c|c|c|c|c|c|c|}
\hline & Arkonsas & Kentucky & Mississippi & Missouri & Tennessee & $\begin{array}{c}\text { Central } \\
\text { Mississippi } \\
\text { Valley }\end{array}$ & Fllinois & Indiana & $\begin{array}{l}\text { United } \\
\text { States }\end{array}$ \\
\hline \multicolumn{10}{|l|}{ Number of Farms } \\
\hline Total 1966 & 78,000 & 140,000 & 104,000 & 157,000 & 145,000 & 624,000 & 136,000 & 112,000 & $3,251,500$ \\
\hline Annual Rate of Change $1956-66$ & $-47 \%$ & -2.6 & -5.8 & -2.2 & -2.7 & -3.4 & -2.5 & -2.7 & -3.2 \\
\hline \multicolumn{10}{|l|}{ Acres per Farm } \\
\hline Average 1966 & 231 & 124 & 148 & 210 & 108 & 159 & 221 & 164 & 351 \\
\hline Annual Rate of Change $1956-66$ & $4.6 \%$ & 1.9 & 2.9 & 1.6 & 1.4 & 2.4 & 2.2 & 2.0 & 2.9 \\
\hline \multicolumn{10}{|l|}{ Number of Fartit Workers } \\
\hline Total 1966 & 127,000 & 198,000 & 162,000 & 213,000 & 196,000 & 896,000 & 185,000 & 159,000 & $5,259,000$ \\
\hline Annual Rote of Change 1956.66 & $-6.4 \%$ & -2.2 & -6.6 & -3.4 & -2.6 & -4.2 & -4.0 & -4.4 & -3.9 \\
\hline \multicolumn{10}{|l|}{ Assets per Farm } \\
\hline Total 1966 & $\$ 59,085$ & 37.102 & 43,516 & 56.697 & 32,041 & 44,673 & 128,293 & 87,131 & 78,662 \\
\hline Annual Rate of Change 1956.66 & $9.5 \%$ & 7.4 & 9.2 & 7.1 & 6.7 & 7.8 & 7.2 & 7.2 & 7.7 \\
\hline \multicolumn{10}{|l|}{ Liabilities per Farm } \\
\hline Total 1966 & $\$ 10,184$ & 5,437 & 6,214 & 9,180 & 5,089 & 7,021 & 15,846 & 11,741 & 12,749 \\
\hline Annual Rafe of Change $1956-66$ & $16.5 \%$ & 11.0 & 14.8 & 10.6 & 12.8 & 12.7 & 10.5 & 11.0 & 11.9 \\
\hline \multicolumn{10}{|l|}{ Equily per Farm } \\
\hline Total 1966 & $\$ 48,901$ & 31,666 & 37,302 & 47.517 & 26,951 & 37,652 & 112,446 & 75,391 & 65,913 \\
\hline Annual Rate of Change $1956-66$ & $8.5 \%$ & 7.0 & 8.5 & 6.5 & 5.8 & 7.1 & 6.8 & 6.7 & 7.0 \\
\hline \multicolumn{10}{|l|}{ Cash Receipts per Farm } \\
\hline Totel 1966 & $\$ 11,656$ & 5,438 & 7.218 & 8.713 & 4,271 & 7,065 & 20,658 & 12,949 & 13,187 \\
\hline Annual Rate of Change $1956-66$ & $8.6 \%$ & 5.9 & 8.8 & 5.3 & 5.4 & 6.7 & 6.4 & 5.9 & 7.0 \\
\hline \multicolumn{10}{|l|}{ Net Income per Form } \\
\hline Tolat 1966 & $\$ 4,913$ & 2,841 & 3,515 & 3,777 & 1,958 & 3,232 & 7,114 & 4,848 & 4,493 \\
\hline Annual Rote of Charge $1956-66$ & $7.1 \%$ & 6.1 & 6.6 & 5.1 & 2.8 & 5.4 & 7.6 & 6.9 & 6.2 \\
\hline
\end{tabular}


nessee was lowest in the area, Kentucky second lowest, and both well below the national average. Furthermore, neither state gained in farm receipts or net income at the national rate during the past decade. Net income in Kentucky rose at the rate of 6.1 per cent, somewhat above the area rate but slightly below the 6.2 per cent rate for the nation. Tennessee, with rates of increase of 5.4 per cent in cash receipts and 2.8 per cent in net income, continued to fall further behind the area and the nation in both measures of farm productivity.

The change in farm size and productivity was rapid in Arkansas and Mississippi in contrast to the relatively low rates of change in Tennessee and Kentucky. The number of farm workers declined more than 6 per cent in each state, 50 per cent faster than either the area or the nation. Acres per farm in Arkansas increased more rapidly than in the nation, while Mississippi equaled the national rate of increase. Assets and liabilities per farm also rose at greater than average rates. In turn, the high growth rates of farm size and capitalization were reflected by rapid gains in productivity. Cash receipts increased 8.6 per cent annually in Arkansas and 8.8 per cent in Mississippi, far exceeding the gain of any other Valley state and well above the national average of 7 per cent. Net income growth was similarly higher in Arkansas and Mississippi with rates of 7.1 and 6.6 per cent, respectively, compared with 6.2 per cent for the nation.

The significance of these changes from the viewpoint of farm credit agencies is their impact on the terms and quantity of credit demanded. For example, real estate loans are generally in great demand in states where farm size is increasing rapidly. Larger farms usually require more expensive specialized machinery. An increase in farm size is commonly associated with machinery efficiencies, thus reducing total machinery costs per unit of output. More intensive farming on small farms is likely to require a relatively large quantity of short-term and intermediate-term credit for current operating expenses, and for purchasing livestock, machinery, and equipment.

From a social viewpoint, credit may be looked upon as a catalyst which facilitates farm adjustments in response to changing market forces. If farm credit agencies are able to tap freely the loanable funds market and make loans to farmers at competitive rates, farm adjustments are likely to occur faster than in the absence of freely functioning credit agencies.

The problem of how much of the nation's stock of credit should be allocated to agriculture will likely resolve to the greatest social benefit under free markets for loanable funds, given appropriate credit institutions. One might expect capital to flow to the sections of the economy where returns to capital are greatest. Returns to capital in agriculture relative to returns in other sectors of the economy would thus determine the volume of credit obtained by farmers.

Production resources for the individual farm are basically acquired in three ways-outright ownership, renting, or custom hiring. Those operators who prefer to expand through the ownership route can move with greater speed with the use of credit. For example, by using mortgage credit requiring a one third downpayment, an operator can purchase three times as much land as he could purchase with cash. Similarly, larger quantities of other production resources such as machinery, livestock, and fertilizer can be obtained quickly via the credit ronte.

\section{Commercinl Banks are Major Supplier of Production Credit}

Commercial banks have historically been the leading institutional supplier of non-real estate farm credit. Prior to the Great Depression of the early $1930^{\prime} s$, banks were the only institutional lenders of importance in this field. By the late 1930's, the Production Credit Associations (PCA's) and the Farmers Home Administration (FHA) had become important suppliers of such credit. The former supplied about 13 per cent and the latter 30 per cent. Commercial banks supplied the remaining 57 per cent of the $\$ 1.5$ billion non-real estate loans reported by institutional lenders. Following World War II, commercial banks were in a highly liquid condition and eager to acquire additional loans. Their holdings of non-real estate farm credit increased rapidly as demand rose, and by 1956 , banks share of the total had increased to 76 per cent of the $\$ 4.4$ billion outstanding to reporting lenders (Table VII). The share held by the PCA's rose to 15 per cent of the total, and that held by the FHA declined sharply to less than 10 per cent of that held by reporting lenders.

During the decade ending in 1966, the total volume of farm production loans outstanding at lending institutions increased sharply from $\$ 4.4$ billion in 1956 to $\$ 11.0$ billion in 1966 . Nationally, the share of farm credit held by banks declined from 76 to 70 per cent of the total. In the Central Mississippi Valley states, however, the banks' proportion dropped more sharply from 72 to 57 per cent of the outstanding amount. Banks in Illinois and Indiana did somewhat better, with declines from 83 to 79 per cent, and 73 to 66 per cent, respectively. 
Restrictions Have

\section{Beera Harmful}

Much of the decline in the share of farm production loans held by banks in the Central Mississippi Valley states can probably be traced to restrictions on banking at the state level. During the decade shares held by banks in Kentucky and Tennessee dropped from 75 to 52 per cent and 74 to 45 per cent, respectively. Banks in each of these two states were above the area average in share of production loans held in 1956, and each dropped well below the average in 1966. Both states have relatively low maximum interest rate limits which are particularly effective in the case of single-payment farm loans. Interest rates rose during the decade, and by 1966 market rates generally had exceeded permissible rates on single-payment loans in these states.

Rates charged farmers in Kentucky and Tennessee averaged 6.1 and 6.2 per cent, respectively, in mid1966, well below the 6.7 per cent average for all area banks and significantly lower than rates on similar loans in the next lowest state (Table V). It is apparent that once market rates on farm loans reached the maximum permissible rates in Kentucky and Tennessee, banks found more profitable opportunities in which to invest their funds, such as instalment and discounted real estate loans. Consequently, more thorough screening of farm credit requests developed. An additional handicap probably prevailed for Tennessee banks where rates paid on time deposits were limited to 4 per cent. As returns from alternative investment opportunities rose above this permissible maximum rate, bank funds from this source tended to rise at a slower rate. All industries, including agriculture, were hampered by this diversion of funds from normal credit supply agencies.

Instead of providing low-cost credit to farmers, these limitations may have restricted the movement of credit into agriculture. They have probably been a factor in the slower rate of growth in farm size and the lower level of income per farm in these states.
Table VII

STATE DEBT HELD BY PRINCIPAL REPORTING LENDERS N CENTRAL MISSISSIPPI VALLEY STATES

$(1956-1966)$

\begin{tabular}{|c|c|c|c|c|c|}
\hline \multicolumn{6}{|c|}{ Per Cent Held By: } \\
\hline \multicolumn{2}{|c|}{$\begin{array}{c}\text { All Operating } \\
\text { Banks }\end{array}$} & \multicolumn{2}{|c|}{$\begin{array}{c}\text { Production Credit } \\
\text { Associations }\end{array}$} & \multicolumn{2}{|c|}{$\begin{array}{l}\text { Farmers Home } \\
\text { Administration }\end{array}$} \\
\hline 1956 & 1966 & 1956 & 1966 & 1956 & 1966 \\
\hline $66.6 \%$ & $51.3 \%$ & $11.5 \%$ & $40.6 \%$ & $21.9 \%$ & $8.1 \%$ \\
\hline 74.6 & 51.6 & 17.8 & 43.3 & 7.6 & 5.1 \\
\hline 50.3 & 54.3 & 23.2 & 32.5 & 26.5 & 13.2 \\
\hline 79.2 & 71.2 & 12.5 & 23,9 & 8.3 & 4.9 \\
\hline 73.7 & 45.3 & 18.9 & $\$ 9.7$ & 7.4 & 5.0 \\
\hline 72.4 & 57.3 & 15.6 & 36.2 & 12.0 & 6.5 \\
\hline 83.3 & 79.0 & 13.5 & 17.6 & 3.2 & 3.4 \\
\hline 72.5 & 65.5 & 22.9 & 31.4 & 4.6 & 3.1 \\
\hline 75.9 & 70.0 & 14.8 & 23.5 & 9.3 & 6.5 \\
\hline
\end{tabular}

\section{Banks Hold Smaller Proportion of Fam Mortgages}

Commercial banks have historically held a relatively small proportion of outstanding farm real estate debt. In the late 1920 's, banks held about 11 per cent of such debt in the nation, and by the late 1930's their share had declined to less than 8 per cent. Following World War II these loans began to increase rapidly, and in 1956 such holdings had increased to 15 per cent of the total. During the past decade the proportion declined slightly to 14 per cent. In 1966, banks in the Central Mississippi Valley held a larger share of total farm real estate debt than banks in the nation. Counter to the national trend, the share held by area banks rose from 21 to 23 per cent during the past decade (Table VIII).

State restrictions on interest rates may have also hampered bank lending on real estate security in Temnessee and Kentucky, In both states farm lending at banks, as well as life insurance companies, declined relative to other farm lenders as generally rising interest rates permitted higher alternative returns for funds. Most of the decline at banks and insurance companies was picked up by Federal Land Banks, which are limited to farm real estate financing.

\section{Sxmmary}

A study of data on bank loans to farmers in the Central Mississippi Valley shows that bank credit to agriculture has responded to the changing credit demands of the industry. The volume of credit extended 
Table V目I

FARM MORTGAGE DEBT HELD BY PRINCIPAL LENDERS IN CENTRAL MISSISSIPPI VALLEY STATES (1956-1966)

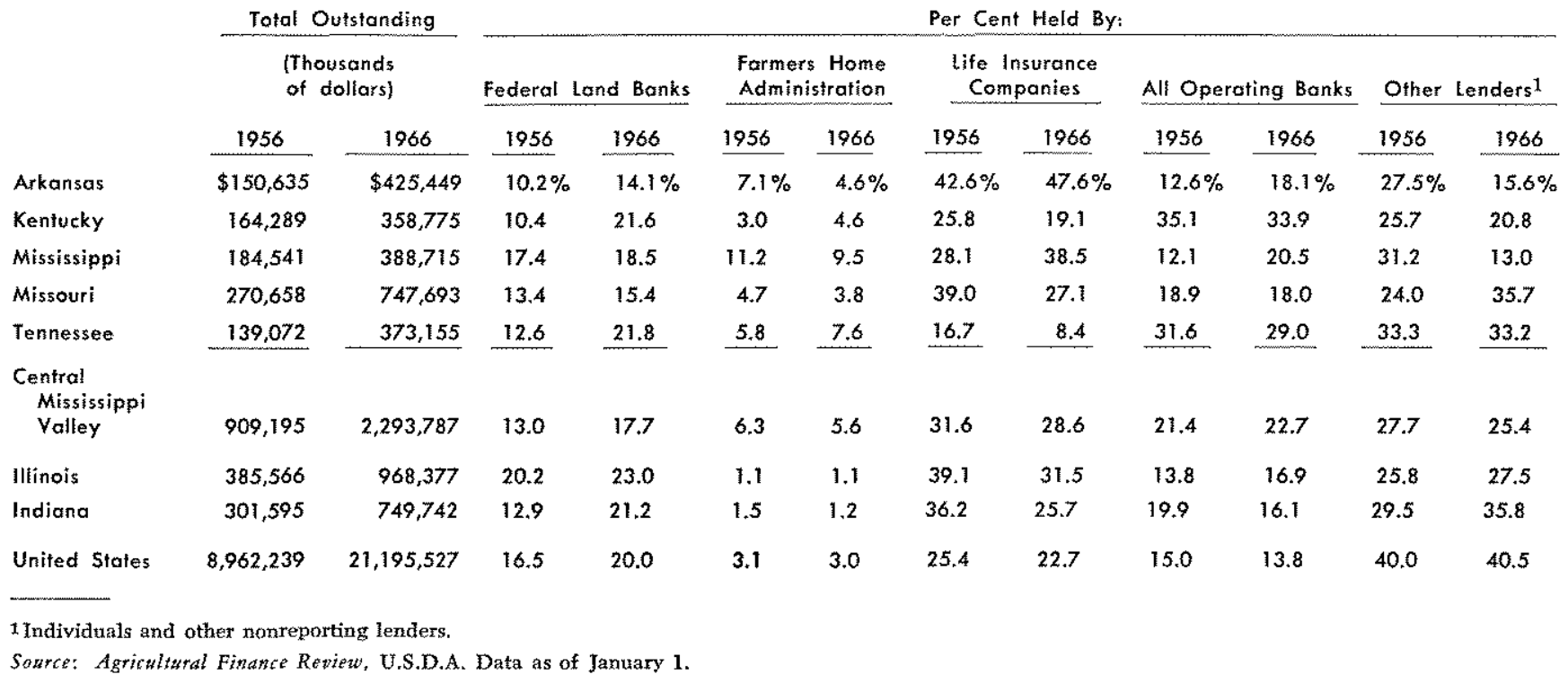

to farmers by banks in the area was 2.5 times greater in mid-1966 than a decade earlier. Loans for increasing the size of business and thereby the level of operating performance constituted a larger proportion of bank loans to farmers. Although seasonal credit is still quite prevalent, the average maturities have been lengthened to terms more in line with the expected flow of returns from new investments.

Nationally, a larger proportion of loans in 1966 were made with short-term maturities than in the region. Conversely, a smaller share of bank loans to farmers in the nation had maturities exceeding 43 months.

Interest rates on bank loans to farmers averaged 6.7 per cent in both the region and the nation. Rates tend. ed to vary with size of loan, purpose of loan, net worth of borrower, and origin of note.

Local banks are depending more on correspondent banks than a decade earlier for assistance in meeting farm credit demands. Participation loans rose as a share of the total, Much of the gain probably reflected an increase in overlines which cannot be handled completely by the local bank because of statutory limitations and safety considerations.

Changes in the terms and quantity of bank credit to farmers reflect in part the changing structure of agriculture. Assets and debt per farm rose sharply during the past decade in both the nation and the
Central Mississippi Valley states. Average farm size and production also increased while the use of labor declined.

Average rates of change did not vary greatly bem tween the Central Mississippi Valley and the nation as a whole. Significant differences are found, however, among the five Valley states. Slower-than-average rates of growth in farm size occurred in Tennessee and Kentucky where the size of farms was already well below average. In contrast, greater-than-average rates of change occurred in Arkansas and Mississippi, boostm ing net income per farm in Arkansas above the national average and that in Mississippi to about 80 per cent of the national level.

Changes in the structure of agriculture have had an important impact on the terms and quantity of farm credit demanded. Credit availability may in turn have facilitated adjustments in response to new technology and market conditions.

Commercial banks have historically been one of the leading sources of non-real estate farm credit. Their share of the total declined somewhat during the past decade. The relative decline was much greater in the Central Mississippi Valley states than in the nation. This greater decline in the area may in part reflect re. strictions on banking in two states where the share held by banks declined the most.

Ceifton B. Lutrakel.

Whiliam E. Pettricrew 